\title{
Aromatase Knockout Mice Show Normal Steroid-Induced Activation of Gonadotrophin-Releasing Hormone Neurones and Luteinising Hormone Surges With a Reduced Population of Kisspeptin Neurones in the Rostral Hypothalamus
}

\author{
L. Szymanski and J. Bakker \\ GIGA Neurosciences, University of Liège, Liège, Belgium.
}

\section{Journal of Neuroendocrinology}

Correspondence to:

Julie Bakker, GIGA Neurosciences, University of Liège B36, Avenue de I'Hopital, 4000 Liège, Belgium (e-mail: jbakker@ulg.ac.be).
We recently reported that female aromatase knockout (ArKO) mice show deficits in sexual behaviour and a decreased population of kisspeptin-immunoreactive neurones in the rostral periventricular area of the third ventricle (RP3V), resurrecting the question of whether oestradiol actively contributes to female-typical sexual differentiation. To further address this question, we assessed the capacity of ArKO mice to generate a steroid-induced luteinising hormone ( $\mathrm{LH})$ surge. Adult, gonadectomised wild-type (WT) and ArKO mice were given silastic oestradiol implants s.c. and, 1 week later, received s.c. injections of either oestradiol benzoate (EB) followed by progesterone, EB alone, or no additional steroids to activate gonadotrophin-releasing hormone $(\mathrm{GnRH})$ neurones and generate an LH surge. Treatment with $\mathrm{EB}$ and progesterone induced significant Fos/GnRH double-labelling and, consequently, an LH surge in female WT and in ArKO mice of both sexes but not in male WT mice. ArKO mice of both sexes had fewer cells expressing Kiss-1 mRNA in the RP3V compared to female WT mice but had more Kiss-1 mRNA-expressing cells compared to WT males, reflecting an incomplete sexual differentiation of this system. To determine the number of cells expressing kisspeptin, the same experimental design was repeated in Experiment 2 with the addition of groups of WT and ArKO mice that were given $E B+$ progesterone and sacrificed $2 \mathrm{~h}$ before the expected $\mathrm{LH}$ surge. No differences were observed in the number of kisspeptin-immunoreactive cells $2 \mathrm{~h}$ before and at the time of the $\mathrm{LH}$ surge. The finding that ArKO mice of both sexes have a competent $\mathrm{LH}$ surge system suggests that oestradiol has predominantly defeminising actions on the $\mathrm{GnRH} / \mathrm{LH}$ surge system in males and that the steroid-induced LH surge can occur in females even with a greatly reduced population of kisspeptin neurones in the RP3V.

Key words: aromatase, kisspeptin, sexual differentiation, oestradiol, hypothalamus.

doi: $10.1111 / j .1365-2826.2012 .02334 . x$
The capacity to generate a preovulatory surge of gonadotrophinreleasing hormone $(\mathrm{GnRH})$ /luteinising hormone $(\mathrm{LH})$ in response to gonadal steroids is perhaps the most robust sexually differentiated endocrine response in rodents, with only females being capable of generating regular LH surges. The release of LH from the pituitary is stimulated by the secretion of $\mathrm{GnRH}$ from a diffuse population of neurones in the hypothalamus, which is in turn modulated by the actions of circulating oestradiol and progesterone. During most of the oestrous cycle, oestrogens exert a negative-feedback on the hypothalamic-pituitary axis. By contrast, on the afternoon of pro-oe- strous, oestrogens and/or progesterone exert a positive-feedback on the hypothalamic-pituitary axis, leading to a massive release of $\mathrm{GnRH}$ and, subsequently, $\mathrm{LH}$, and in turn to ovulation, at the same time as facilitating sexual behaviour (1-3). Thus, ovarian oestradiol secreted from metoestrous through early pro-oestrous by the developing follicle stimulates the release of $\mathrm{GnRH}$ and sensitises the pituitary gland to become more responsive to hypothalamic GnRH (4). The hypothalamic-pituitary axis in males, on the other hand, does not show positive-feedback in response to oestradiol and males are not able to support ovulation when implanted with ovarian tissue as adults (5). 
This sex difference in the GnRH/LH surge system appears to be organised by the perinatal actions of testosterone and/or oestradiol on the hypothalamus $(6,7)$. In rodents, neonatal castration feminises the ability of males to show the capacity to generate an $\mathrm{LH}$ surge, and treatment with testosterone or oestradiol in the neonatal period will prevent the development of the GnRH/LH surge system in females (8-10). In males, testosterone is secreted from the developing testis and is subsequently aromatised in the brain and other tissues to oestradiol by the enzyme aromatase. Prenatal treatment with the aromatase inhibitor, 1,4,6-androstatrien-3,17-dione disrupts $\mathrm{LH}$ responses to oestradiol in adult male guinea pigs (11), and affects male-typical sex behaviour in guinea pigs (12), sheep (13) and rats (14-16), indicating that the prenatal aromatisation of testosterone to oestradiol is crucial to the normal development of reproductive behaviours and responses to gonadal hormones in adulthood. Accordingly, perinatal treatment with exogenous oestradiol defeminises the $\mathrm{GnRH} / \mathrm{LH}$ system in female rats $(9,17,18)$. Further evidence for a defeminising role for oestradiol is found in female mice which, as a result of a targeted mutation of the Afp gene, lack the foetal circulating oestradiol-binding protein, $\alpha$-foetoprotein and thus the protection against maternal oestrogens (19). Previous work in our laboratory shows that Afp null female mice do not show any LH surges after treatment with oestradiol and progesterone (20), indicating that exposure to oestradiol during the prenatal period defeminises the $\mathrm{GnRH}$ surge system. However, the exact mechanism by which oestradiol defeminises the potential to show such steroid-induced LH surges has not been fully identified.

It is possible that another neuropeptide system organised by oestradiol also plays a role in the organization of the $\mathrm{GnRH} / \mathrm{LH}$ surge system. Recent studies have focused on the role of kisspeptin, a small peptide that appears to play a crucial role in $\mathrm{GnRH}$ secretion. Kisspeptin stimulates $\mathrm{GnRH}$ secretion via its receptor, GPR54 (now known as Kiss1r), which is present on GnRH neurones (21). Treatment with kisspeptin stimulates LH secretion in many species, including mice (22), rats $(23)$, sheep $(21,24)$, monkeys (25) and humans (26). Treatment with kisspeptin antibodies or antagonists can block the ability to show an LH surge in female rats $(27,28)$. In addition, the expression of this peptide is sexually dimorphic in rodents: the number of kisspeptin neurones in the rostral periventricular area of the third ventricle (RP3V), an area comprised of the anteroventral periventricular (AVPV), periventricular preoptic and median preoptic nuclei (29), is much higher in females than in males (30), suggesting that this brain area may play an important role in the sexually dimorphic control of $\mathrm{GnRH}$ secretion. Another population of kisspeptin neurones exists in the arcuate nucleus; however, this population is not sexually dimorphic in adulthood and not considered to be implicated in the generation of the LH surge in rodents (31). Kisspeptin neurones express oestradiol receptor (ER) $\alpha$ and progesterone receptors (32-34) and oestradiol treatment increases kisspeptin expression in the RP3V (35), whereas GnRH neurones only appear to contain $E R \beta$, which does not appear to mediate the effects of oestradiol on the generation of the GnRH/LH surge (3638). These findings suggest that kisspeptin neurones likely modulate the effects of gonadal steroids on $\mathrm{GnRH}$ secretion. However, the effects of deletion of the kisspeptin (Kiss-1) gene or Kiss1r gene on

Journal of Neuroendocrinology, 2012, 24, 1222-1233 the $\mathrm{GnRH} / \mathrm{LH}$ surge system do not provide consistent support for the necessity of kisspeptin in the generation of steroid-induced $\mathrm{LH}$ surges. One group has found that neither Kiss-1, nor Kiss1r null mice are capable of generating steroid-induced LH surges (34). By contrast, another group using a different transgenic mouse line has shown that Kiss1r null mice are capable of generating a steroidinduced LH surge (39). Furthermore, Kiss-1r and Kiss null male mice show increased LH secretion in response to central, but not peripheral treatment with NMDA, a potent stimulator of LH secretion (40). Lastly, female mice in which the majority of kisspeptin- or Kiss1rexpressing neurones have been genetically ablated show ovarian follicles in all stages of development and are fertile (41), suggesting that normal reproductive development can occur in the absence of kisspeptin signalling to $\mathrm{GnRH}$ neurones. These conflicting results may not only be a result of differences in mouse strains used, but they also illustrate that the role of kisspeptin in the generation of the LH surge is not completely understood.

Although there is a strong defeminising role for oestradiol in the development of the $\mathrm{GnRH}$ surge system, recent data obtained in female aromatase knockout (ArKO) mice that cannot synthesise oestradiol from its androgenic precursor as a result of a targeted mutation in the Cyp19 gene also suggest that oestradiol may be necessary to feminise the kisspeptin system. Female ArKO mice treated with oestradiol and progesterone in adulthood show decreased levels of lordosis behaviour when paired with a sexually active male and have reduced numbers of kisspeptin neurones in the $\operatorname{RP3V}(42,43)$. Oestradiol treatment alone fails to induce ovulation in female ArKO mice (44), indicating a possible link between the lack of ovulation (and presumably steroid-induced LH surges) and the absence of a female-typical population of kisspeptin in the RP3V. Clarkson and Herbison (45) have shown that ovariectomy of female mice at postnatal day (P)15 results in a 70-90\% reduction in kisspeptin expression within the RP3V analysed at either P30 or $\mathrm{P} 60$, whereas treatment with $17 \beta$-oestradiol in P15-ovariectomised mice from $\mathrm{P} 15-30$ or $\mathrm{P} 22-30$ resulted in a complete restoration of kisspeptin expression in this brain region, indicating that oestradiol can affect the organisation of the kisspeptin system after the perinatal period. Conversely, female rats treated with oestradiol at birth show reduced numbers of kisspeptin-expressing neurones in the rostral hypothalamus (9). Taken together, these results suggest that oestradiol not only affects the organisation of the brain during the prenatal and neonatal period, but also can act during the prepubertal period to organise the kisspeptin system.

Therefore, in the present study, we tested the hypothesis that oestradiol is necessary to feminise the capacity to show preovulatory LH surges by determining whether female ArKO mice are capable of showing steroid-induced $\mathrm{LH}$ surges. In addition, we also investigated the potential of ArKO males to show steroid-induced $\mathrm{LH}$ surges aiming to confirm the hypothesis that oestradiol defeminises the potential to show preovulatory $\mathrm{LH}$ surges in this sex. If oestradiol only defeminises the potential to show an LH surge, we would expect that both ArKO males and females would show an $\mathrm{LH}$ surge. If oestradiol is required to feminise the LH surge system, we would expect that neither ArKO males, nor ArKO females would show a steroid-induced surge of LH. Interestingly, ArKO males and 
ArkO females have low numbers of kisspeptin neurones (43); thus, if ArKO mice fail to show a steroid-induced LH surge, this may be a result of this decreased population of kisspeptin neurones in the RP3V. To test the hypothesis that a female-typical number of kisspeptin neurones is necessary for a steroid-induced LH surge, the number of cells expressing Kiss-1 mRNA and kisspeptin protein in the RP3V of ArKO mice was determined at and around the time of the expected LH surge.

\section{Materials and methods}

\section{Animals}

The present study used aromatase knockout mice with a targeted disruption of exons 1 and 2 of the Cyp19 gene $(46,47)$. All breeding and genotyping were carried out at the department GIGA Neurosciences, University of Liège, Belgium. Heterozygous males and females of the CD1 (Swiss-Webster) strain were bred to generate wild-type (WT) and knockout (ArKO) offspring. Genotyping was performed by polymerase chain reaction analysis of tail DNA (48). Food and water were available ad lib. and the temperature was maintained at $22{ }^{\circ} \mathrm{C}$. All experiments were conducted in accordance with the guidelines set forth by the National Institutes of Health Guiding Principles for the Care and Use of Research animals and were approved by the Ethical Committee for Animal Use of the University of Liege.

\section{Surgery}

Adult (3-6 months) WT and ArKO mice of both sexes were anaesthetised using an s.c. injection of ketamine ( $80 \mathrm{mg} / \mathrm{kg}$ per mouse) and medetomidine (Domitor, Pfizer (Domitor Pfizer Animal Health BV, Capelle a/d ljssel, the Netherlands; $1 \mathrm{mg} / \mathrm{kg}$ per mouse) and the gonads were removed. At the same time as gonadectomy, all mice were implanted s.c. with a silastic capsule ( $5 \mathrm{~mm}$ in length, inner diameter $1 \mathrm{~mm}$, outer diameter $2 \mathrm{~mm}$ ) containing $1 \mu \mathrm{g}$ of $17 \beta$-oestradiol dissolved in $7.35 \mu \mathrm{l}$ of sesame oil (SO) to maintain the negative-feedback effects of low levels of oestradiol on circulating gonadotrophins. At the end of surgery, all mice received an s.c. injection of atipamezole (Antisedan, Pfizer; $4 \mathrm{mg} / \mathrm{kg}$ per mouse) to antagonise medetomidine-induced effects and accelerate recovery. After surgery, mice were placed in individual cages, and males and females were housed in different rooms under a reversed $12: 12 \mathrm{~h}$ light/dark cycle.

\section{Experiment 1: Determinination of whether ArKO mice can generate a steroid-induced activation of $\mathrm{GnRH}$ neurones and a plasma $\mathrm{LH}$ surge}

\section{Hormone treatment}

One week (7 days) after gonadectomy, WT and ArKO mice were divided into three groups: Group 1 mice [oestradiol benzoate $(E B)$ + progesterone $(P): W T / m a l e$, $n=10 ;$ ArKO/male, $n=11$; WT/female, $n=9$; ArKO/female, $n=8$ ] received an s.c. injection of EB $(1 \mu \mathrm{g} / 20 \mathrm{~g}$ body weight/ $0.05 \mathrm{ml}$ of SO) $4 \mathrm{~h}$ before the onset of the dark period (day 8) and, $24 \mathrm{~h}$ later (day 9), an s.c. injection of progesterone (500 $\mu \mathrm{g}$ in $0.05 \mathrm{ml}$ of SO) to induce an LH surge; group 2 mice (EB only: WT/male, $n=11$; ArKO/male, $n=11 ;$ WT/female, $n=7 ;$ ArKO/female $n=8$ ) received only an $\mathrm{EB}$ injection (day 8 ) and nothing on day 9 , and group 3 mice (implant only: WT/male, $n=10 ;$ ArKO/male, $n=11 ;$ WT/female, $n=6$; ArKO/female, $n=7$ ) received no additional steroid injections on either day 8 or day 9. At the expected time of the LH surge (within $1 \mathrm{~h}$ of the onset of the dark period, day 9 of treatment), mice were anaesthetised with an overdose of ketamine (160 mg/kg/mouse) and medetomidine ( $2 \mathrm{mg} / \mathrm{kg} / \mathrm{mouse}$ ). Approximately $1 \mathrm{ml}$ of blood was drawn via cardiac puncture for LH assay. Next, all mice were perfused transcardially with saline followed by $4 \%$ cold paraformaldehyde. Brains were removed and post-fixed in 4\% paraformaldehyde for $2 \mathrm{~h}$ at room temperature (RT). Brains were then placed in a $30 \%$ sucrose solution at $4{ }^{\circ} \mathrm{C}$ until they sank, and were then frozen on dry ice and stored at $-80^{\circ} \mathrm{C}$. Brains were sliced coronally on a cryostat from the rostral telencephalon to the posterior hypothalamus making four sets of $30 \mu \mathrm{m}$ sections. Sections were saved in cryoprotectant solution and stored at $-20{ }^{\circ} \mathrm{C}$ for immunohistochemistry for $\mathrm{GnRH} /$ Fos and in situ hybridisation for Kiss-1 mRNA levels. As a result of technical problems, not all samples used for immunohistochemistry had sufficient tissue remaining for in situ hybridisation, and the group numbers used for in situ hybridisation were: for $E B+P$ treatment: WT/males, $n=7 ;$ ArKO/males, $n=7$; WT/females, $n=6$; ArKO/females, $n=6$; for $E B$ only treatment: WT/males, $n=4$; ArKO/males, $n=5$; WT/females, $n=6$; ArKO/females, $n=6$; for implant only treatment: WT/males, $n=5$; ArKO/males, $n=6$; WT/females, $n=5 ;$ ArKO/females, $n=5$.

\section{Immunohistochemistry and data analysis for paraformaldehyde-fixed tissue}

We previously showed that the steroid-induced LH surge was accompanied by an induction of Fos, the protein product of the immediate early gene, c-Fos, in GnRH neurones (20). Therefore, in the present study, we performed double-labelling immunohistochemistry on the brain sections to determine the co-localisation of Fos- and GnRH-expressing neurones in the preoptic area. Primary antibodies were specific for Fos polyclonal antibody (dilution 1 : 2000; sc-52 rabbit Fos pAB; Santa Cruz Biotechnology Inc., Santa Cruz, CA, USA) and GnRH I [dilution 1: 1000; GnRH I (FI-92); Santa Cruz Biotechnology, Inc., Santa Cruz, CA, USA]. In experiment 1, double-label immunohistochemistry sections were first rinsed in $0.01 \mathrm{M}$ phosphate-buffered saline (PBS) ( $\mathrm{pH} \mathrm{7.4),} \mathrm{then} \mathrm{peroxidase} \mathrm{activity} \mathrm{was} \mathrm{blocked} \mathrm{in} \mathrm{a} 1: 4$ methanol : PBS solution with $3 \% \mathrm{H}_{2} \mathrm{O}_{2}$. After peroxidase blocking, sections were rinsed in PBS- $0.1 \%$ Triton-X 100 (PBST) and then incubated in a solution of $5 \%$ normal goat serum (NGS) in PBST. Sections were then incubated overnight in a solution of Fos Ab in NGS (Fos Ab, dilution $1: 2000$ ) at $4{ }^{\circ} \mathrm{C}$. The next day, sections were rinsed in PBST, and then incubated in polyclonal goat anti-rabbit biotinylated secondary antibody (dilution $1: 1000$ in PBST; Dako, Glostrup, Denmark) for $1 \mathrm{~h}$ at RT. Sections were washed in PBST and incubated in the Vectastain Elite ABC Kit (PK6100; Vector Laboratories, Burlingame, CA, USA), then rinsed in PBST. After rinsing in a solution of $0.05 \mathrm{M}$ Tris- $\mathrm{HCl}$, sections were developed with the DAB substrate Kit (SK-4100; Vector Laboratories) to give a black precipitate $\left[3,3^{\prime}\right.$-diaminobenzidine (DAB) $+\mathrm{Ni}^{2+}$. Sections were then rinsed in MilliQ $\mathrm{H}_{2} \mathrm{O}$ (Millipore, Billerica, MA, USA) followed by $\mathrm{PBS}$, re-fixed in $4 \%$ paraformaldehyde and the residual peroxidase activity was blocked in 1:4 methanol : PBS solution. Sections were rinsed in PBST then incubated in GnRH pAb (dilution $1: 1000$ ) at $4{ }^{\circ} \mathrm{C}$ for $24 \mathrm{~h}$, respectively. Next, secondary antibody and $A B C$ steps were performed as described above, and the tissue was developed using Vector NovaRED substrate Kit (SK-4800; Vector Laboratories) to produce a red precipitate. Sections were then mounted on slides, dried and cover slipped in Eukitt (Sigma, Bornem, Belgium).

For $\mathrm{GnRH}$ and Fos/GnRH double-labelled cells, the counting area was located within the preoptic area (interaural 4.42-4.30 mm and Bregma $0.62-0.50 \mathrm{~mm}$ ), as previously described (49). Both hemispheres of two brain sections (with an interval of $120 \mu \mathrm{m}$ between sections) were counted.

\section{In situ hybridisation of Kiss mRNA levels: preparation of riboprobe}

A plasmid containing mouse Kiss1 riboprobe was generously provided by $\mathrm{Dr}$ Alexander Kauffman (Department of Reproductive Medicine and the Centre 
for Chronobiology, University of California, San Diego, La Jolla, CA, USA). The sequence of the riboprobe spans bases 78-486 of the mouse Kiss1 gene (Genbank accession number AF473576). The plasmid was heat-transfected and amplified in competent Escherichia coli DH5 $\alpha$ cells. The circular plasmid was extracted from these cells and purified using the OIA Filter Plasmid Midi-Kit (Qiagen Inc., Valencia, CA, USA). Plasmids were linearised by incubation with Hindlll restriction enzyme (Roche Diagnostics $\mathrm{GmbH}$, Mannheim, Germany) and the linearised DNA was purified using QIAprep Spin Miniprep Kit (Qiagen Inc.). The antisense Kiss 1 probe was synthesised using $T 7$ transcription enzyme, DIG labelling mix, and RNAase inhibitors (Roche Diagnostics $\mathrm{GmbH}$ ). The antisense probe was purified in Sephadex G-50 columns (Kit-Illustra microspin G50 columns; GE Healthcare, Milwaukee, WI, USA).

\section{In situ hybridisation}

Free-floating brain sections prepared as previously described for immunohistochemistry were used for in situ hybridisation. Sections were washed in PBS-diethylpyrocarbonate (DEPC) then briefly post-fixed with 4\% paraformaldehyde. Sections were washed again in PBS-DEPC and then treated with $100 \mathrm{~mm}$ triethanolamine acetylated with $0.25 \%$ acetic acid. Sections were washed with PBS-Tween $0.1 \%$ and then pre-hybridised with pre-warmed hybridization buffer for $1 \mathrm{~h}$ at $70^{\circ} \mathrm{C}$. Sections were then hybridised with a mix of $4 \mu \mathrm{l}$ DIG-labelled Kiss 1 probe and $250 \mu$ of pre-warmed hybridisation buffer overnight in a $70^{\circ} \mathrm{C}$ water bath. Sections were washed in washing buffer ( $50 \%$ formamide, $2 \times S S C, 0.1 \%$ Tween) at $72{ }^{\circ} \mathrm{C}$, washed in buffer B1 (100 mm Tris- $\mathrm{HCl} \mathrm{pH} 7.5,150 \mathrm{~nm} \mathrm{NaCl}, 0.1 \%$ Tween) at RT, then blocked in buffer B2 (10\% NGS in buffer B1) for $1 \mathrm{~h} 15 \mathrm{~min}$ at RT. Next, tissue was incubated with anti-DIG coupled to alkaline phosphatase (Anti-DIG-AP Fab fragments; Roche Diagnostics $\mathrm{GmbH}$ ) diluted $1: 2000$ in B2 overnight at $4{ }^{\circ} \mathrm{C}$. Tissue was washed in B1 then incubated in B3 (100 mm Tris pH 9.5, $100 \mathrm{~mm} \mathrm{NaCl}, 50 \mathrm{~mm} \mathrm{MgCl} 2,0.1 \%$ Tween) at RT. Next, tissue was added to 3-400 $\mu$ l of filtered NBT/BCIP liquid substrate system (Sigma Aldrich, St. Louis, MO, USA) in the dark for $1 \mathrm{~h}$ at RT. The tissue was transferred to fresh NBT/BCIP and the reaction was allowed overnight in the dark at $4{ }^{\circ} \mathrm{C}$ until the desired signal was reached. Tissue was washed in PBS-Tween to stop the reaction, and was mounted on slides in an aqueous gelatin medium and coverslipped. After allowing the slides to dry, Kiss 1-mRNA containing cells were counted. The counting areas were limited to the rostral hypothalamus within interaural: 4.06-3.94 mm and Bregma 0.26-0.14 mm according to Franlyn and Paxinos (50). Both hemispheres of two to four brains sections (with an interval of $120 \mu \mathrm{m}$ between sections) were counted.

\section{Experiment 2: comparison of numbers of kisspeptin-immunoreactive neurones before and after the steroid-induced LH surge in ArKO versus WT mice}

In Experiment 1, we observed that ArKO mice of both sexes were clearly capable of showing a steroid-induced LH surge at the same time as having a decreased level of Kiss-1 mRNA expression in the RP3V, which might question the role of kisspeptin in regulating the preovulatory $\mathrm{LH}$ surge. Therefore, we conducted a second experiment to determine the expression of kisspeptin protein before and during the steroid-induced surge of $\mathrm{LH}$.

\section{Hormone treatment}

A new batch of WT and ArKO mice was gonadectomised and implanted with silastic capsules containing oestradiol as described in Experiment 1. One week (7 days) after gonadectomy, mice were divided into four groups: group 1 mice received a s.c. injection of oestradiol benzoate (EB) $(1 \mu \mathrm{g} / 20 \mathrm{~g}$ body weight $/ 0.05 \mathrm{ml}$ of S0) $4 \mathrm{~h}$ before the onset of the dark period (day 8) and, $24 \mathrm{~h}$ later (day 9), an s.c. injection of progesterone ( $500 \mu \mathrm{g}$ in $0.05 \mathrm{ml}$ of SO) to induce an LH surge. Two animals had plasma LH concentrations that were more than ten-fold lower than the others in the same sex/genotype (WT/female, ArKO/male) and so were removed from the study (resulting group numbers for $E B+P$ : WT/male, $n=4 ;$ ArKO/male, $n=3$; WT $/$ female, $n=4$; ArKO/female, $n=5$ ); group 2 mice received only an EB injection (day 8) and nothing on day 9 ( $E B$ only: WT/male, $n=5 ;$ ArKO/male, $n=4$; WT/female, $n=6$; ArKO/female, $n=5$ ) and group 3 mice received no additional steroid injections on either day 8 or day 9 (implant only: WT/male, $n=5$; ArKO/female, $n=4 ; W T /$ female, $n=5$; ArKO/female, $n=5$ ). All mice in groups $1-3$ were sacrificed at the expected time of the LH surge (within $1 \mathrm{~h}$ of the onset of the dark period, on day 9 of treatment). An additional group received an injection of EB on day 8 and progesterone on day 9 , and were sacrificed $2 \mathrm{~h}$ before the expected time of the LH surge $(E B+P-2 h$ : WT/male, $n=6$; ArKO/male, $n=4 ;$ WT/female, $n=5$; ArKO/female, $n=5$ ).

At the time of sacrifice, mice were anaesthetised with an overdose of ketamine (160 mg/kg/mouse) and medetomidine ( $2 \mathrm{mg} / \mathrm{kg} / \mathrm{mouse})$. Approximately $1 \mathrm{ml}$ of blood was drawn via cardiac puncture for LH assay. Next, the brains were removed and fixed in 5\% acrolein solution for $2.5 \mathrm{~h}$, and then rinsed $2 \times 30 \mathrm{~min}$ in PBS at RT. We used acrolein as fixative because we observed only few kisspeptin-immunoreactive (-IR) neurones in ArKO mice when brains were fixed with paraformaldehyde (43). In addition, the type of fixative used for immunohistochemistry can affect staining (51). Brains were then placed in a $30 \%$ sucrose solution at $4{ }^{\circ} \mathrm{C}$ until they sank, and were then frozen on dry ice and stored at $-80{ }^{\circ} \mathrm{C}$ until use. Brains were sliced coronally on a cryostat from the rostral telencephalon to the posterior hypothalamus, making four sets of $30-\mu \mathrm{m}$ sections. Sections were saved in cryoprotectant solution and stored at $-20^{\circ} \mathrm{C}$ for immunohistochemistry. .

\section{Immunohistochemistry and data analysis for acrolein-fixed tissue}

We performed double-labelling immunohistochemistry on the brain sections to determine the co-localization of Fos- and Kisspeptin-IR neurones in the rostral hypothalamus. Immunohistochemical procedures were very similar to those described for Experiment 1, with the exception that all rinses were performed in Tris buffer solution ( $\mathrm{pH} \mathrm{7.4)} \mathrm{and} \mathrm{that} \mathrm{sections} \mathrm{were} \mathrm{first} \mathrm{incu-}$ bated in 1\% sodium borohydride solution and tissue was developed with the DAB substrate Kit (SK-4100; Vector Laboratories) to give a brown precipitate for kisspeptin immunoreactivity. Primary antibodies were specific for Fos polyclonal antibody (dilution $1: 2000$; sc-52 rabbit Fos pAB, Santa Cruz Biotechnology Inc.), and kisspeptin (dilution 1 : 5000; rabbit pAb donated by Dr A. Caraty, UMR Physiologie de la Reproduction et des Comportements, INRA, Nouzilly France). Sections were incubated in kisspeptin antibody for $72 \mathrm{~h}$ at $4^{\circ} \mathrm{C}$. This concentration of kisspeptin antibody was chosen after testing with lower and higher concentrations and found to provide the best quality labelling in our laboratory. For Kisspeptin and Fos/Kisspeptin doublelabelled cells, the counting areas were limited to the rostral hypothalamus within interaural: $4.06-3.94 \mathrm{~mm}$ and Bregma $0.26-0.14 \mathrm{~mm}$ according to Franklin and Paxinos (50). Both hemispheres of three to four brains sections (with an interval of $120 \mu \mathrm{m}$ between sections) were counted.

\section{LH analysis}

Serum LH levels were determined in duplicate in a volume of $100 \mu \mathrm{l}$ using a double-antibody method and radioimmunoassay kits, kindly supplied by the National Institute of Health (Dr A. F. Parlow, National Institute of Diabetes and Kidney Diseases, National Hormone and Peptide Program, Torrance, $C A$, USA). Rat LH-I-10 (AFP-11536 B) was labelled with ${ }^{125}$ I by the chloramine-T method. The hormone concentrations were expressed using the mouse $\mathrm{LH}$ reference preparation (AFP-5306A) as standard. The intra-assay and interassay coefficients of variations were less than $7 \%$ and $10 \%$ respectively. The sensitivity of the assay was $0.04 \mathrm{ng} / \mathrm{ml}$. 


\section{Statistical analysis}

Two-way ANovas with genotype/sex and treatment as factors were carried out for all dependent variables (STATISTICA, version 9; StatSoft, Inc., Tulsa, OK, USA). When appropriate, the ANovas were followed by Fisher's least significant difference post-hoc comparisons (for the percentage Fos/GnRH data, the one-tailed test was used, whereas a two-tailed test was used for all other data). $P<0.05$ was considered statistically significant.

\section{Results}

Experiment 1: Determinination of whether ArKO mice can generate a steroid-induced activation of $\mathrm{GnRH}$ neurones and a plasma $\mathrm{LH}$ surge

\section{Plasma LH levels}

Treatment with $E B+P$ induced a $L H$ surge in WT females and ArKO mice of both sexes but not in WT males (Fig. 1A), supporting the hypothesis that oestradiol defeminises the GnRH/LH surge system. The two-way anova indicated a significant effect of genotype/sex $\left(F_{3,97}=12.43, P<0.0001\right)$, treatment $\left(F_{2,97}=28.58, P<0.0001\right)$ and a significant genotype/sex $\times$ treatment interaction $\left(F_{6,97}=8.22\right.$, $P<0.0001$ ). Post-hoc analysis showed that, in WT female mice, treatment with $E B+P$ resulted in higher plasma concentrations of $\mathrm{LH}$ compared to $E B$ treatment $(\mathrm{P}<0.05)$ or implant alone $(P<0.01)$. ArKO female mice treated with $E B+P$ also showed significantly higher plasma concentrations of $\mathrm{LH}$ than ArKO female mice given $E B(P<0.0001)$ or implant only $(P<0.0001)$, indicating that female ArKO mice are capable of showing steroid-induced $\mathrm{LH}$ surges. ArKO males treated with EB $+\mathrm{P}$ had significantly higher concentrations of plasma $\mathrm{LH}$ than ArKO males treated with $\mathrm{EB}$ $(P<0.0001)$ or given an implant only $(P<0.0001)$, and ArKO males treated with $E B+P$ also had significantly higher concentrations of plasma $L H$ than WT males given $E B+P(P<0.0001)$, indicating that ArKO males are also capable of showing steroid-induced $L H$ surges. WT male mice treated with EB $+\mathrm{P}$ had significantly lower plasma concentrations of $\mathrm{LH}$ than WT male mice given an implant only $(P<0.05)$ but did not differ significantly from WT male mice treated with $E B$ only $(P=0.78)$.

\section{Number of GnRH-IR neurones and percentage of double-labelled Fos/GnRH neurones}

In accordance with plasma LH concentrations, subsequent treatment with $\mathrm{EB}+\mathrm{P}$ induced Fos protein in $\mathrm{GnRH}$ neurones in the preoptic area in WT females and ArKO mice of both sexes but not in WT males (Fig. 1B). There were no significant differences between groups in the number of GnRH-IR neurones in the preoptic area (Table 1); however, differences in the percentage of double-labelled Fos/GnRH neurones were found (Fig. 1B). Images of the Fos/GnRH staining are presented in Fig. 2. Two-way Anova revealed significant main effects of genotype/sex $\left(F_{3,97}=7.49, P<0.001\right)$ and treatment $\quad\left(F_{2,97}=18.68, \quad P<0.001\right)$ and a significant genotype/sex $\times$ treatment interaction $\left(F_{6,97}=3.86, P<0.001\right)$. Post-hoc
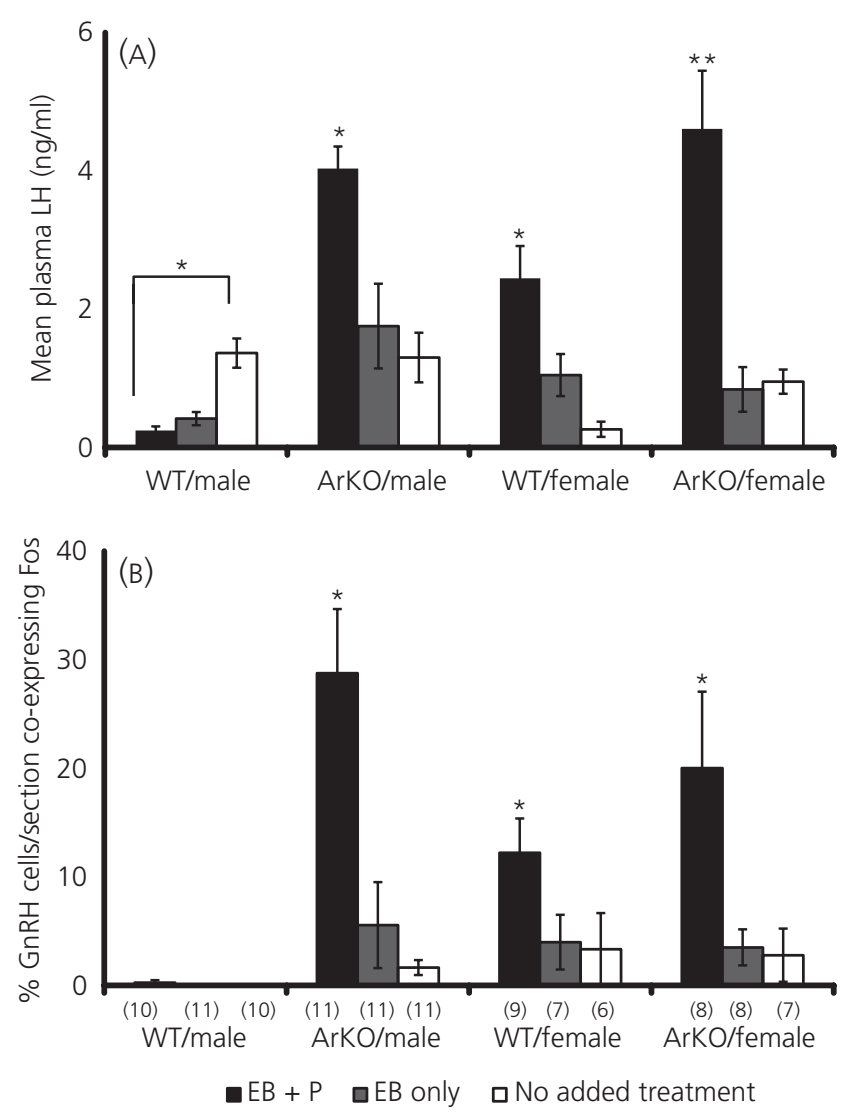

Fig. 1. Capacity of aromatase knockout (ArKO) mice to show a steroid-induced luteinising hormone (LH) surge. (A) Mean \pm SEM plasma concentrations of $\mathrm{LH}$ $(\mathrm{ng} / \mathrm{ml})$ and (B) Mean \pm SEM percentage of gonadotrophin-releasing hormone $(\mathrm{GnRH})$ neurones co-expressing Fos/section in the preoptic area in gonadectomised male and female wild-type (WT) and ArKO mice given a silastic implant containing $1 \mu \mathrm{g}$ of $17 \beta$-oestradiol in $7.35 \mu \mathrm{l}$ of sesame oil for 1 week, then treated with injections of oestradiol benzoate (EB) and progesterone $(E B+P)$, oestradiol only ( $E B$ only) or no further injections (no added treatment). ${ }^{*} P<0.05$. $\left.{ }^{*} P<0.01\right)$. The number of animals per experimental group is given in parentheses.

analysis indicated that WT female mice treated with $E B+P$ had a higher percentage of double-labelled Fos/GnRH neurones than WT female mice treated with $E B(P=0.05)$ or implant only $(P=0.05)$, and also differed significantly from $W T$ males treated with $E B+P$ $(P<0.05)$. ArKO female mice treated with $E B+P$ also showed a significantly higher percentage of double-labelled Fos/GnRH neurones than ArKO female mice given $E B(P<0.01)$ or implant only $(P<0.01)$. ArKO males treated with $E B+P$ had a higher percentage of double-labelled Fos/GnRH neurones than ArKO males treated with $E B(P<0.0001)$ or implant only $(P<0.0001)$, and ArKO males treated with $E B+P$ had a significantly higher percentage of double-labelled Fos/GnRH neurones than WT males treated with $E B+P(P<0.0001)$, indicating that the $L H$ surge produced in WT female mice and ArKO mice of both sexes in response to $E B+P$ is accompanied by a significant co-expression of Fos in GnRH neurones. 
Table 1. Mean \pm SEM Number of Gonadotrophin-Releasing Hormone $(\mathrm{GnRH})$ Neurones in the Preoptic Area in Gonadectomised Male and Female Wild-Type (WT) and Aromatase Knockout (ArKO) Mice Given a Silastic Implant Containing $1 \mu \mathrm{g}$ of $17 \beta$-Oestradiol in $7.35 \mu$ l of Sesame Oil for 1 Week, Then Treated With Injections of Oestradiol Benzoate (EB) and Progesterone (EB + P), Oestradiol Only (EB only) or No Further Injections (No Added Treatment).

\begin{tabular}{|c|c|c|c|c|c|c|c|c|}
\hline \multirow[b]{2}{*}{ Treatment } & \multicolumn{2}{|l|}{ WT/male } & \multicolumn{2}{|l|}{$\mathrm{KO} / \mathrm{male}$} & \multicolumn{2}{|l|}{ WT/female } & \multicolumn{2}{|l|}{$\mathrm{KO} /$ female } \\
\hline & $\mathrm{GnRH}$ & $\mathrm{n}$ & $\mathrm{GnRH}$ & $n$ & $\mathrm{GnRH}$ & $n$ & $\mathrm{GnRH}$ & $n$ \\
\hline$E B+P$ & $34.6 \pm 5.6$ & 10 & $36.1 \pm 3.4$ & 11 & $26.6 \pm 2.6$ & 9 & $29.5 \pm 4.2$ & 8 \\
\hline EB only & $29.6 \pm 6.2$ & 11 & $30.2 \pm 3.9$ & 11 & $26.1 \pm 3.1$ & 7 & $28.4 \pm 5.3$ & 8 \\
\hline No added treatment & $36 \pm 3.1$ & 10 & $27.3 \pm 3.8$ & 11 & $26.3 \pm 5.2$ & 6 & $27.6 \pm 6.0$ & 7 \\
\hline
\end{tabular}

WT female
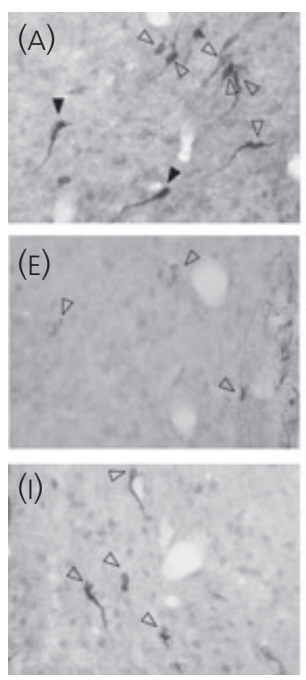

WT male
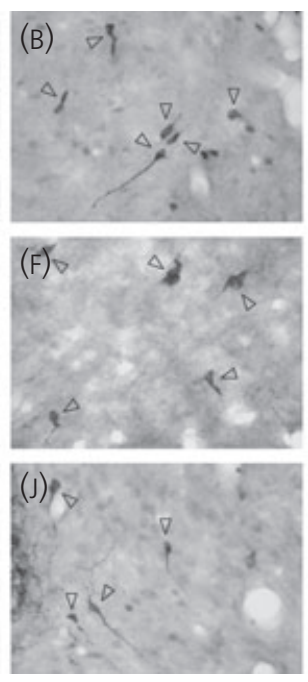

ArKO female
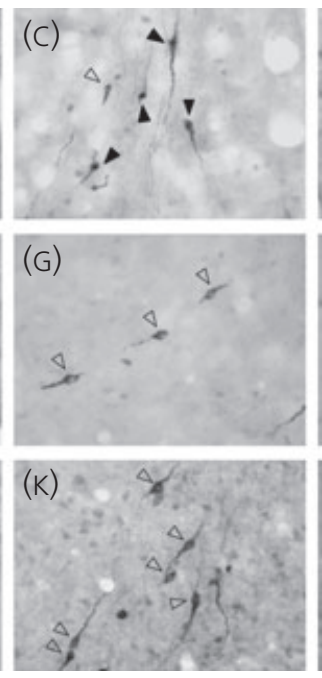

ArKO male
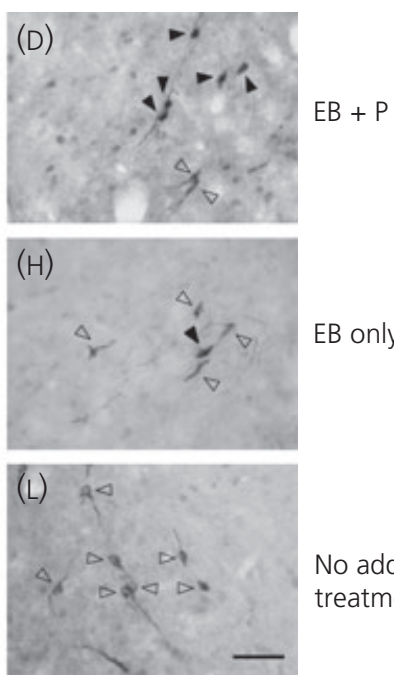

EB only

No additional treatment

Fig. 2. Representative photomicrographs $(\times 40)$ of gonadotrophin-releasing hormone $(\mathrm{GnRH})$ neurones in the preoptic area of gonadectomised male and female wild-type (WT) and aromatase knockout (ArKO) mice given a silastic implant containing $1 \mu \mathrm{g}$ of oestradiol in $7.35 \mu$ l of sesame oil and then treated with injections of oestradiol benzoate and progesterone $(E B+P)$, oestradiol only ( $E B$ only) or no further injections (no additional treatment). (A) Female WT mouse treated with $E B+P$. (B) Male WT mouse treated with $E B+P$. (C) Female ArKO mouse treated with EB + P. (D) Male ArKO mouse treated with EB + P. (E) Female WT mouse treated with EB only. (F) Male WT mouse treated with EB only. (G) Female ArKO mouse treated with EB only. (H) Male ArKO mouse treated with EB only. (I) Female WT mouse given silastic implant only. (J) Male WT mouse given silastic implant only. (K) Female ArKO mouse given silastic implant only. ( $($ ) Male ArKO mouse given silastic implant only. Open arrows indicate GnRH neurones, whereas closed arrows indicated Fos-activated GnRH neurones. Scale bar $=50 \mu$ m.

\section{Number of neurones containing Kiss-1 mRNA}

ArKO mice were capable of generating a steroid-induced LH surge despite having significantly fewer Kiss-1 expressing cells in the RP3V compared to WT female mice (Fig. 3), which does not support the hypothesis that WT female-typical numbers of kisspeptin neurones in the RP3V are necessary for the generation of the $\mathrm{LH}$ surge. Two-way ANova of the number of neurones containing Kiss-1 mRNA in the RP3V revealed that there were significant main effects of genotype $/$ sex $\left(F_{3,56}=150.81, P<0.001\right)$ but no significant effect of treatment or genotype/sex $\times$ treatment interaction. Post-hoc analysis confirmed that WT female mice had a significantly higher number of neurones containing Kiss-1 mRNA in the RP3V than WT males and ArKO mice of both sexes, regardless of hormonal treatment $(P<0.01)$. WT males had a significantly lower number of neurones containing Kiss- 1 mRNA in the RP3V than WT females and ArKO mice of both sexes $(P<0.01)$.
Experiment 2: Comparison of numbers of kisspeptin-IR neurones before and after the steroid-induced LH surge in ArKO versus WT mice

\section{Number of kisspeptin-IR neurones and percentage of double-labelled Fos/kisspeptin neurones in acrolein-fixed tissue}

As shown previously (43), WT female mice had a greater number of kisspeptin-IR neurones in the RP3V than WT male mice and ArKO mice of both sexes at the expected time of the $L H$ surge, regardless of hormonal treatment (Fig. 4A). The number of kisspeptin-IR neurones in $E B+P$ treated mice killed $2 \mathrm{~h}$ before the expected surge of $\mathrm{LH}$ was not significantly different from that at the time of the $\mathrm{LH}$ surge. Thus, the low numbers of kisspeptin-IR neurones in ArKO male and female mice showing a steroid-induced surge of $L H$ is not likely the result of a $E B+P$ induced depletion of kisspeptin 


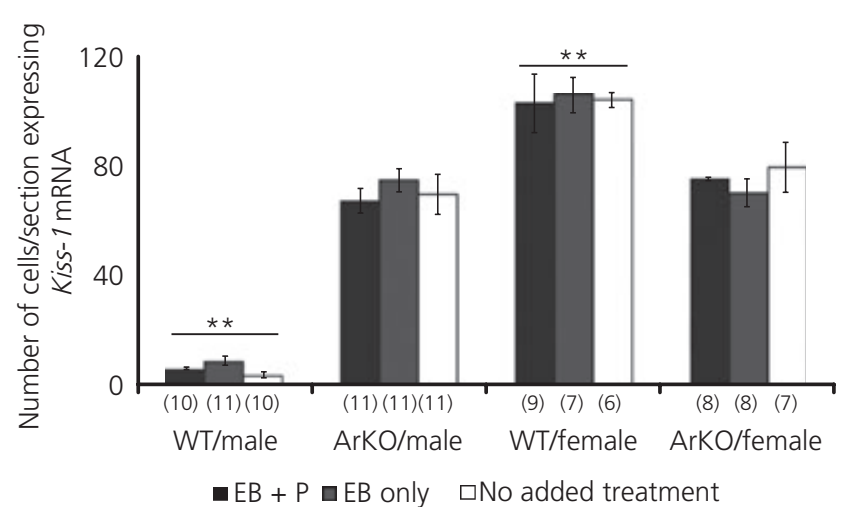

Fig. 3. Mean \pm SEM number of Kiss-1 mRNA-expressing neurones/section in the rostral periventricular area of the third ventricle of gonadectomised male and female wild-type (WT) and aromatase knockout (ArKO) mice given a silastic implant containing $1 \mu \mathrm{g}$ of $17 \beta$-oestradiol in $7.35 \mu \mathrm{l}$ of sesame oil for 1 week, then treated with injections of oestradiol benzoate and progesterone $(E B+P)$, oestradiol only (EB only) or no further injections (no added treatment). ${ }^{* *} P<0.01$. The number of animals per experimental group is given in parentheses.

in the RP3V. The two-way ANova of the number of kisspeptin-IR neurones in the RP3V revealed significant main effects of genotype/sex $\left(F_{3,60}=118.29, P<0.001\right)$ but no significant effect of treatment or genotype/sex $\times$ treatment interaction. Post-hoc analysis of this effect revealed that WT female mice had a higher number of kisspeptin-IR neurones/section than WT male mice and ArKO mice of both sexes $(P<0.001)$. WT male mice had a lower number of kisspeptin-IR neurones/section than WT females and ArKO mice of both sexes $(P<0.001)$.

WT female mice had a higher percentage of double labelled Fos/kisspeptin neurones/section in the RP3V compared to WT male mice and ArKO mice of both sexes (Fig. 4B). Two-way ANOVA of the number of double-labelled Fos/kisspeptin-neurones in the RP3V revealed significant main effects of genotype/sex $\left(F_{3,60}=95.40\right.$, $P<0.001)$ but no significant effect of treatment or genotype/sex $\times$ treatment interaction. Post-hoc analysis of this effect revealed that WT female mice had a higher percentage of doublelabelled Fos/kisspeptin neurones than WT males and ArKO mice of both sexes, regardless of treatment $(P<0.001)$. WT males had a lower percentage of double-labelled Fos/kisspeptin neurones than WT and KO females, regardless of treatment $(P<0.05)$. Images of Fos/Kisspeptin staining are presented in Fig. 5.

\section{Plasma LH levels}

As observed in Experiment 1, treatment with $\mathrm{EB}+\mathrm{P}$ induced a $\mathrm{LH}$ surge in WT females and ArKO mice of both sexes but not in WT males (Fig. 6). As a result of technical problems, two samples could not be analysed (the adjusted group numbers are noted). Two-way ANOVA indicated a significant effect of genotype/sex $\left(F_{3,58}=10.23\right.$, $P<0.001)$, treatment $\left(F_{3,58}=10.99, P<0.001\right)$ and a significant genotype/sex $\times$ treatment interaction $\left(F_{9,58}=6.72, \quad P<0.001\right)$. Post-hoc analysis showed that, in WT female mice, treatment with
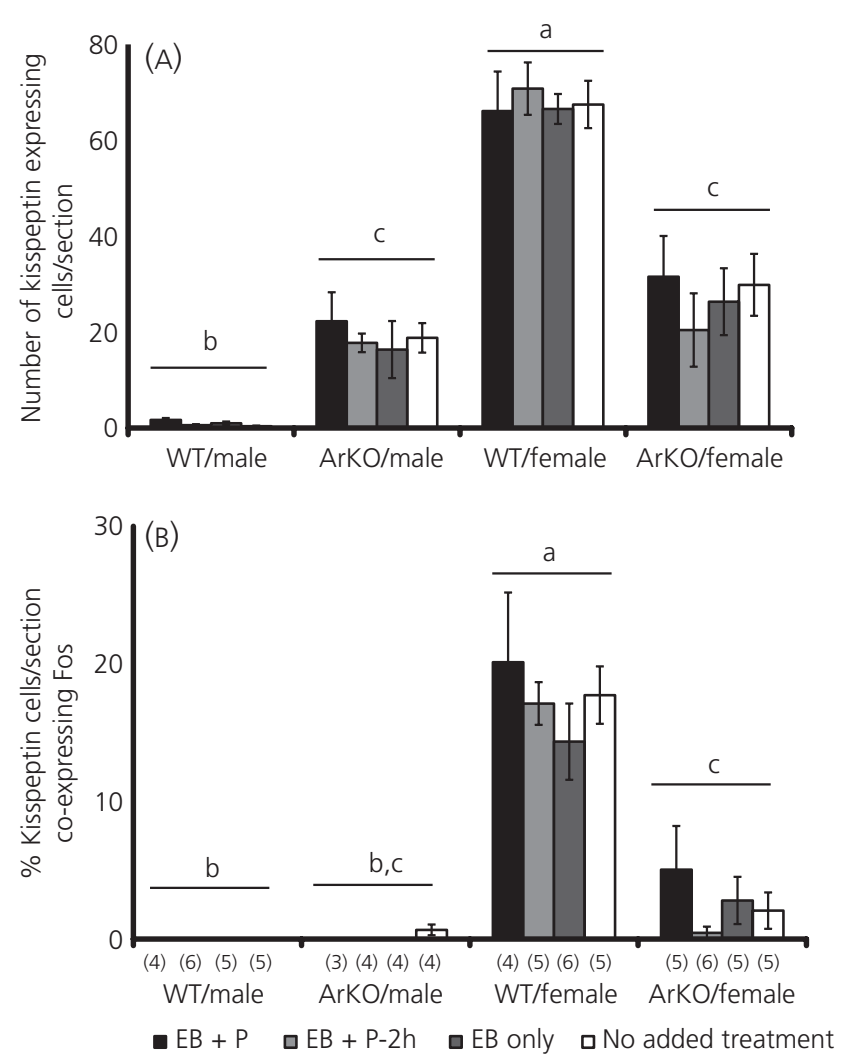

Fig. 4. (A) Mean \pm SEM number of kisspeptin-expressing neurones/section and (B) mean \pm SEM percentage of kisspeptin-immunoreactive neurones coexpressing Fos-IR/section in the rostral periventricular area of the third ventricle of gonadectomised male and female wild-type (WT) and aromatase knockout (ArKO) mice given a silastic implant containing $1 \mu \mathrm{g}$ of $17 \beta$-oestradiol in $7.35 \mu \mathrm{l}$ of sesame oil for 1 week, then treated with injections of oestradiol benzoate (EB) and progesterone $(\mathrm{P})$ and sacrificed $2 \mathrm{~h}$ before the expected luteinising hormone (LH) surge ( $E B+P-2 h)$, or sacrificed at the expected time of the LH surge after injections of oestradiol benzoate and progesterone $(E B+P)$, oestradiol only (EB only) or no further injections (no added treatment). Groups with different letter notations are significantly different from one another within the same genotype/sex $(P<0.05)$. The number of animals per experimental group is given in parentheses.

$\mathrm{EB}+\mathrm{P}$ resulted in higher plasma concentrations of $\mathrm{LH}$ compared to implant only $(P<0.05)$. ArKO female mice treated with $E B+P$ also had significantly higher plasma concentrations of $\mathrm{LH}$ than all other groups $(P<0.05)$, indicating that female ArKO mice are capable of showing steroid-induced LH surges. In addition, the fact that ArKO females treated with $E B+P$ had significantly higher plasma concentrations than ArKO females treated with $E B+P$ and sacrificed $2 \mathrm{~h}$ before the expected surge $(E B+P-2 h, P<0.001)$ indicates that the LH surge is occurring at the time of sacrifice $(4 \mathrm{~h}$ after progesterone injection, within $1 \mathrm{~h}$ of the onset of the dark period) in these animals. Similarly, ArKO males treated with $E B+P$ had significantly higher concentrations of plasma LH than ArKO males given an implant only $(P<0.001)$ and ArKO males treated with $E B+P$ and sacrificed $2 \mathrm{~h}$ before the expected time of the LH surge $(P<0.0001)$. As observed in Experiment $1, W T$ male mice treated with $E B+P$ had significantly lower plasma concentrations of $L H$ 
WT female
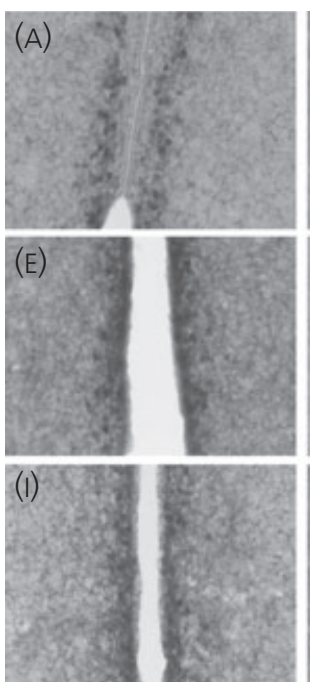

WT male
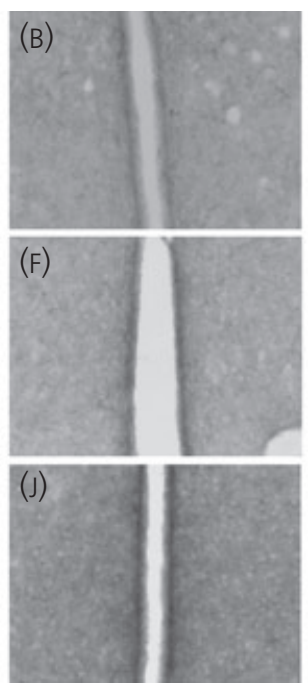

ArKO female
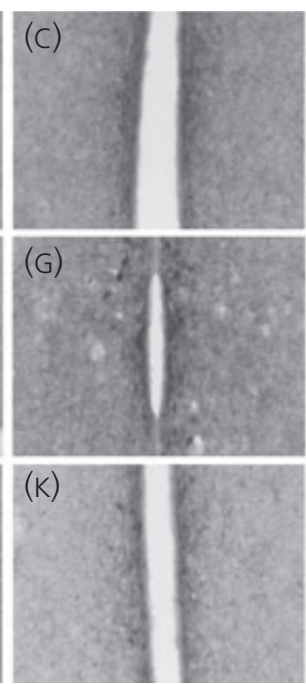

ArKO male
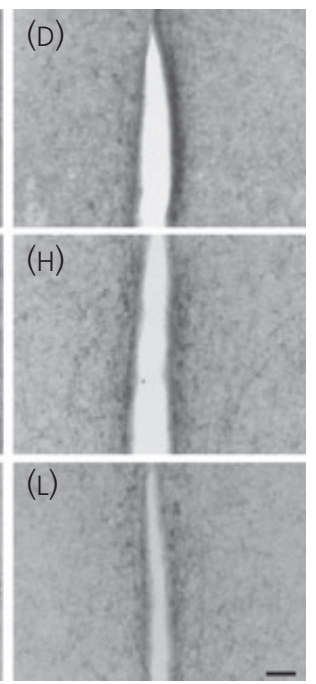

$E B+P$

$E B+P-2 h$

No additional

treatment

Fig. 5. Representative photomicrographs $(\times 20)$ of kisspeptin and Fos/kisspeptin neurones in the rostral periventricular area of the third ventricle of gonadectomised male and female wild-type (WT) and aromatase knockout (ArKO) mice given an silastic implant containing $1 \mu \mathrm{g}$ of oestradiol in $7.35 \mu \mathrm{l}$ of sesame oil then treated with injections of oestradiol benzoate and progesterone $(E B+P)$, oestradiol and progesterone then sacrificed $2 \mathrm{~h}$ prior to the expected time of the $L H$ surge $(E B+P-2 h$ ), or no further injections (no additional treatment). (A) Female WT mouse treated with EB + P. (B) Male WT mouse treated with $E B+P$. (c) Female ArKO mouse treated with $E B+P$. (D) Male ArKO mouse treated with $E B+P$. (E) Female WT mouse treated with $E B+P-2 h$. (F) Male WT mouse treated with $E B+P-2 h$. (G) Female ArKO mouse treated with $E B+P-2 h$. (H) Male ArKO mouse treated with EB $+P-2 h$. (I) Female WT mouse given silastic implant only. (J) Male WT mouse given silastic implant only. (K) Female ArKO mouse given silastic implant only. (L) Male ArKO mouse given silastic implant only. Scale bar $=50 \mu \mathrm{m}$.

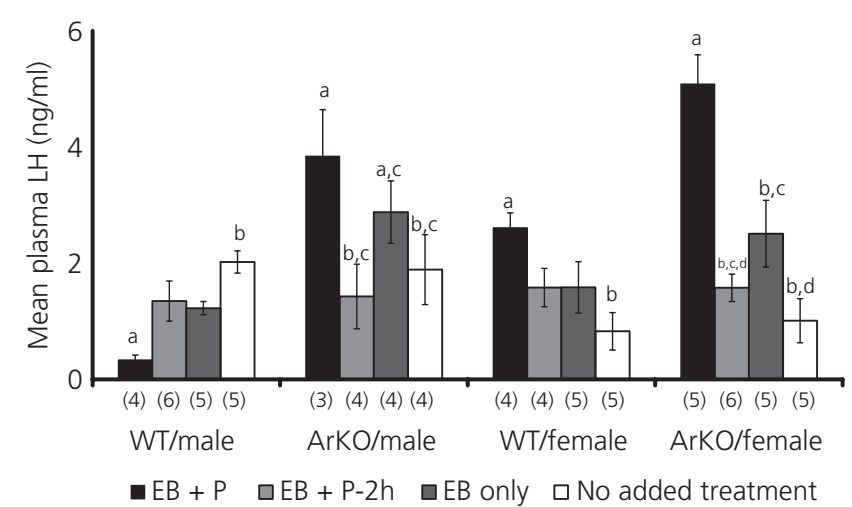

Fig. 6. Capacity of aromatase knockout (ArKO) mice to show a steroidinduced luteinising hormone $(\mathrm{LH})$ surge. Mean \pm SEM plasma concentrations of $\mathrm{LH}(\mathrm{ng} / \mathrm{ml})$ in gonadectomised male and female WT and ArKO mice given a silastic implant containing $1 \mu \mathrm{g}$ of $17 \beta$-oestradiol in $7.35 \mu \mathrm{l}$ of sesame oil for 1 week, then treated with injections of oestradiol benzoate (EB) and progesterone $(\mathrm{P})$ and sacrificed $2 \mathrm{~h}$ before the expected $\mathrm{LH}$ surge $(E B+P-2 h)$ or sacrificed at the expected time of the LH surge after injections of oestradiol and progesterone $(E B+P)$, oestradiol only (EB only) or no further injections (implant only). Groups with different letter notations are significantly different from one another within the same genotype/sex $(P<0.05)$. The number of animals per group is given in parentheses.

than WT male mice given an implant only $(P<0.05)$. It is important to note that there were no significant differences between sex/genotype in the $E B+P-2 h$ groups, indicating that, $2 \mathrm{~h}$ before the expected time of the LH surge, there is no difference in plasma concentrations of $\mathrm{LH}$ between sex or genotype. Thus, the timing of the expected $\mathrm{LH}$ surge is likely to be accurate in this experiment.

\section{Discussion}

The present study shows that both male and female ArKO mice were capable of generating an $\mathrm{LH}$ surge in response to adult treatment with $E B+P$, lending further support to the idea that oestradiol defeminises the capacity to show steroid-induced activation of $\mathrm{GnRH}$ neurones and, by consequence, an LH surge in male mice. The finding that female ArKO mice showed LH surges when treated with $E B+P$ in adulthood indicates that this particular female characteristic develops in the absence of any previous developmental action of oestradiol. Development of this female-typical neuroendocrine circuit differs from the organisation of the neural circuits underlying courtship behaviours, which require feminisation by oestradiol during prepubertal development $(42,52)$. Oestradiol presumably acts prenatally because female mice that lack $\alpha$-foetoprotein, a foetal circulating oestradiol-binding protein that protects against maternal oestradiol (19), do not show an LH surge after treatment with $\mathrm{EB}+\mathrm{P}(49)$.

Interestingly, ArKO mice did not have female-typical numbers of kisspeptin-IR or Kiss-1 mRNA expressing neurones in the RP3V, indicating that the steroid-induced $\mathrm{LH}$ surge occurred with a reduced population of kisspeptin neurones. Furthermore, kisspeptin neurones in ArKO mice showed reduced Fos co-expression after $\mathrm{EB}+\mathrm{P}$ treatment compared to WT female mice, raising the 
question of whether this reduced population of kisspeptin neurones in the RP3V of ArKO females, as well as ArKO males, is essential for the generation of the steroid-induced $\mathrm{GnRH} / \mathrm{LH}$ surge. Kisspeptin has been proposed to be an important player in the cyclic generation of preovulatory LH surges because Kiss1r and Kiss1 null mice do not show an $\mathrm{LH}$ surge or Fos/GnRH double-labelling in response to $E B+P$. However, a different strain of Kiss1r null mice retains the capacity to generate a steroid-induced LH surge (39). Similarly, recent work by Mayer and Boehm (41) showed that female mice, in which over 95\% of kisspeptin- or Kiss1r-expressing neurones were ablated during embryonic development, show all stages of oestrous cyclicity and were fertile in adulthood. However, when kisspeptinor Kiss1r-expressing neurones are ablated in adulthood, only females in which Kiss1r-expressing neurones are ablated remained fertile (41). Nevertheless, there is evidence questioning the absolute requirement of the full female-typical complement of kisspeptin neurones in generating $\mathrm{GnRH} / \mathrm{LH}$ surges.

The ArKO mouse model permits the study of the differentiation of the GnRH surge system and the kisspeptin system in the absence of oestradiol exposure across development. Although female ArKO mice have altered ovarian phenotype and are infertile (53), our results showed that the $\mathrm{GnRH} / \mathrm{LH}$ surge system was still capable of generating a steroid-induced $\mathrm{LH}$ surge in these mice. ArKO mice typically show increased plasma concentrations of gonadotrophins (presumably as a result of the lack of negative-feedback by oestradiol), although treatment with a low dose of oestradiol decreases plasma LH concentrations to normal levels (53, 54). Our observation of low levels of plasma LH in implant-only treated ArKO mice of both sexes is consistent with this finding. ArKO mice are also characterised by higher levels of androgens in adulthood as a result of the absence of negative-feedback actions of oestradiol on the hypothalamic-pituitary-gonadal axis (47). It has been shown that, in male mice, treatment with androgens in adulthood can affect kisspeptin expression in the arcuate nucleus and median eminence, although the Kiss-1 population in the RP3V appears to be less affected (55). Thus, it is more likely that the reduced population of kisspeptin neurones in the RP3V of ArKO mice is a result of the absence of oestradiol during a critical prepubertal period (45) than that it has been defeminised by androgens. If the latter was true, then ArKO males should have had a maletypical population of kisspeptin neurones in the RP3V. Typically, ArKO female mice do not show ovulation in response to oestradiol treatment in adulthood; however, recently, it has been discovered that combined treatment with oestradiol, pregnant mare serum gonadotrophin and human chorionic gondatrophin can indeed induce ovulation in ArKO female mice (56), suggesting that the reproductive system has the capacity to function despite high levels of circulating gonadotrophins.

There is strong evidence that oestradiol plays an important role in the sexual differentiation of the kisspeptin system during both pre- and postnatal development (31). Neonatal treatment with oestradiol defeminises the population of kisspeptin neurones in the RP3V of females $(9,57,58)$, whereas neonatal castration prevents the defeminisation of the number of Kiss-1 mRNA-expressing neurones in the RP3V in male rats (9). Although the precise

(C) 2012 The Authors.

Journal of Neuroendocrinology (C) 2012 British Society for Neuroendocrinology mechanism of action of oestradiol remains to be elucidated, it is possible that the defeminising actions of oestradiol on kisspeptin result from cell death, similar to the oestradiol-induced cell death in tyrosine hydroxylase-IR neurones in the AVPV (59). Although recent evidence has suggested that the development of the sexually dimorphic number of kisspeptin neurones is not dependent on the proapoptotic protein BAX (B-cell lymphoma 2-associated protein $X)$ (60), it is possible that oestradiol could regulate cell death in RP3V kisspeptin neurones via a BAX-independent apoptotic pathway. It should be noted, however, that the number of Kiss-1 mRNA expressing neurones is lower in neonatally castrated male rats compared to female rats (9), suggesting a postnatal contribution of oestradiol to the development of the kisspeptin system in females. Indeed, our results, as well as those obtained previously $(30,45)$, suggest that oestradiol exerts feminising effects on kisspeptin neuronal development during the prepubertal period. If oestradiol only defeminised the numbers of kisspeptinexpressing neurones in the RP3V, both male and female ArKO mice, which are characterised by the lack of circulating oestradiol throughout development (47), should have had a female-typical population of kisspeptin neurones in the rostral hypothalamus, which is clearly not the case (43). Furthermore, the development of kisspeptin neurones in the RP3V appears to occur between $\mathrm{P} 15$ and $\mathrm{P} 30$, and the sex differences in this neuronal population do not emerge until after $\mathrm{P} 10(30,45)$, which is well past the perinatal surge of testosterone and oestradiol that is considered to be responsible for the defeminisation of the $\mathrm{GnRH} / \mathrm{LH}$ surge system in males $(61,62)$. Taken together, these results show that oestradiol plays a dual role in the sexual differentiation of the kisspeptin population in the RP3V. It has clear defeminising effects when present prenatally (49) and shortly after birth (9,58, 63) that are normally prevented in the female hypothalamus as a result of the presence of oestradiol-binding $\alpha$-foetoprotein. In addition, oestradiol has clear feminising effects during the prepubertal period by inducing a female-typical population of kisspeptin neurones in the RP3V (45). Presumably, kisspeptin neurones in the RP3V in males are either not exposed to adequate feminising levels of oestradiol during this particular prepubertal period or become insensitive to such actions during postnatal development and adulthood. Because ArKO mice are deprived of oestradiol during both the prenatal and prepubertal period, their kisspeptin population is neither defeminised, nor feminised, and thus not completely sexually differentiated. Even so, treatment with $E B+P$ induced $\mathrm{GnRH}$ neurone activation leading to an $\mathrm{LH}$ surge in ArKO mice of both sexes.

In the present study, we observed numbers of kisspeptin-IR neurones and those expressing Kiss-1 mRNA. Consistent with other rodent studies, a clear sex difference was observed, with WT females having higher numbers of Kiss- 1 mRNA neurones than WT males $(32,57,63,64)$. By contrast, the numbers of Kiss-1 mRNA expressing cells were much higher than the numbers of kisspeptinIR neurones for all experimental groups. A similar discrepancy between kisspeptin protein expression and Kiss-1 mRNA content has been reported by Clarkson and Herbison (65), who have shown that kisspeptin cell number or their apposition upon $\mathrm{GnRH}$ 
neurones remain constant throughout the oestrous cycle, in stark contrast to the results obtained in other laboratories, which have shown that Kiss-1 mRNA levels are strongly modulated by gonadal hormones and vary over the course of the oestrous cycle $(35,66)$. The reasons for the discrepancy between kisspeptin protein levels and Kiss 1 mRNA content remain unclear. It could reflect differences in sensitivity between in situ hybridisation for mRNA and immunohistochemistry for the protein. Nevertheless, it is the kisspeptin protein that interacts with $\mathrm{GnRH}$ neurones and thus the essential marker of kisspeptin function (65). This is particularly relevant to the lower numbers of kisspeptin protein containing neurones observed in ArKO mice that were still capable of generating $\mathrm{LH}$ surges in response to $E B+P$ treatment. $A$ possible explanation might have been that kisspeptin stores were already depleted at the time of sacrifice, which presumably coincided with the timing of the LH surge in these animals. However, kisspeptin protein expression (reflected by the number of kisspeptin-IR neurones) in mice sacrificed $2 \mathrm{~h}$ before the expected time of the $\mathrm{LH}$ surge did not differ significantly from those sacrificed at the time of the $\mathrm{LH}$ surge. Thus, it is unlikely that the low number of kisspeptin-IR neurones seen in ArKO mice was the result of a depletion of kisspeptin protein in the RP3V before the LH surge. It is also possible that the kisspeptin system, similar to the $\mathrm{GnRH}$ system, only requires a minimum number of neurones to permit the induction of the $\mathrm{LH}$ surge.

In summary, both male and female ArKO mice showed an activation of hypothalamic $\mathrm{GnRH}$ neurones leading to a plasma $\mathrm{LH}$ surge in response to adult treatment with $E B+P$. This result has two implications. First, the $\mathrm{GnRH} / \mathrm{LH}$ surge control circuit system is normally defeminised in male mice by the early actions of oestradiol. Second, in contrast to its role in feminising the circuits controlling courtship behaviours, oestradiol is not required to feminise the $\mathrm{GnRH} / \mathrm{LH}$ surge control circuit in female mice. Our observation of reduced numbers of kisspeptin-IR neurones in ArKO female mice compared to WT females further suggests that postnatal oestradiol is normally required to feminise the RP3V kisspeptin system. Our unexpected result that hormone-induced activation of $\mathrm{GnRH}$ neurones led to a surge of plasma LH in ArKO mice lacking a female-typical population of RP3V kisspeptin neurones suggests that a reduced number of kisspeptin neurones may be sufficient for a functional $\mathrm{GnRH} / \mathrm{LH}$ surge system in these mice. It is possible that compensatory mechanisms have allowed the surges to proceed with a partially reduced population of kisspeptin neurones in the RP3V in ArKO mice, or that the female-typical number of RP3V kisspeptin neurones is redundant, just as the number of preoptic GnRH neurones in female rodents far exceeds the number needed to generate preovulatory LH surges (41).

\section{Acknowledgements}

The authors thank Arlette Gerard for the execution of the LH assays, as well as Bertrand Thimister and Olivier Brock for technical assistance. We also thank Dr Alexander Kauffman for generously providing the plasmid for Kiss1. This research was funded by FNRS Mandat d'Impulsion F.4502.07, FRSM grant 3.4571.10 and NIH grant HD 044897. Laura Szymanski is a postdoctoral fellow for the FNRS and Julie Bakker is a research associate of the FNRS.
Received 7 December 2011, revised 18 April 2012, accepted 29 April 2012

\section{References}

1 Christian CA, Moenter SM. The neurobiology of preovulatory and estradiol-induced gonadotropin-releasing hormone surges. Endocr Rev 2010; 31: 544-577.

2 Micevych P, Sinchak K. Synthesis and function of hypothalamic neuroprogesterone in reproduction. Endocrinology 2008; 149: 2739-2742.

3 Petersen SL, Ottem EN, Carpenter CD. Direct and indirect regulation of gonadotropin-releasing hormone neurons by estradiol. Biol Reprod 2003; 69: 1771-1778.

4 Herbison AE. Multimodal influence of estrogen upon gonadotropinreleasing hormone neurons. Endocr Rev 1998; 19: 302-330.

5 Harris GW. Hormonal differentiation of the developing central nervous system with respect to patterns of endocrine function. Philos Trans $R$ Soc Lond B Biol Sci 1970; 259: 165-177.

6 Vreeburg JT, van der Vaart PD, van der Schoot P. Prevention of central defeminization but not masculinization in male rats by inhibition neonatally of oestrogen biosynthesis. J Endocrinol 1977; 74: 375-382.

7 Neill JD. Sexual differences in the hypothalamic regulation of prolactin secretion. Endocrinology 1972; 90: 1154-1159.

8 Crowley WR, Kalra SP. Neonatal exposure to estradiol prevents the expression of ovarian hormone-induced luteinizing hormone and prolactin surges in adulthood but not antecedent changes in neuropeptide $Y$ or adrenergic transmitter activity: implications for sexual differentiation of gonadotropin secretion. Brain Res 1994; 663: 257-265.

9 Homma T, Sakakibara M, Yamada S, Kinoshita M, Iwata K, Tomikawa J, Kanazawa T, Matsui H, Takatsu Y, Ohtaki T, Matsumoto H, Uenoyama Y, Maeda K, Tsukamura H. Significance of neonatal testicular sex steroids to defeminize anteroventral periventricular kisspeptin neurons and the $\mathrm{GnRH} / \mathrm{LH}$ surge system in male rats. Biol Reprod 2009; 81: 1216-1225.

10 Corbier P. Sexual differentiation of positive feedback: effect of hour of castration at birth on estradiol-induced luteinizing hormone secretion in immature male rats. Endocrinology 1985; 116: 142-147.

11 Choate JV, Resko JA. Prenatal inhibition of aromatase activity affects luteinizing hormone feedback mechanisms and reproductive behaviors of adult guinea pigs. Biol Reprod 1994; 51: 1273-1278.

12 Roy MM, Goy RW. Sex differences in the inhibition by ATD of testosterone-activated mounting behavior in guinea pigs. Horm Behav 1988; 22: 315-323.

13 Roselli CE, Schrunk JM, Stadelman HL, Resko JA, Stormshak F. The effect of aromatase inhibition on the sexual differentiation of the sheep brain. Endocrine 2006; 29: 501-511.

14 Whalen RE, Gladue BA, Olsen KL. Lordotic behavior in male rats: genetic and hormonal regulation of sexual differentiation. Horm Behav 1986; 20: 73-82.

15 Brand T, Kroonen J, Mos J, Slob AK. Adult partner preference and sexual behavior of male rats affected by perinatal endocrine manipulations. Horm Behav 1991; 25: 323-341.

16 Bakker J, Brand T, van Ophemert J, Slob AK. Hormonal regulation of adult partner preference behavior in neonatally ATD-treated male rats. Behav Neurosci 1993; 107: 480-487.

17 Aihara M, Hayashi S. Induction of persistent diestrus followed by persistent estrus is indicative of delayed maturation of tonic gonadotropin-releasing systems in rats. Biol Reprod 1989; 40: 96-101.

18 Gorski RA. Modification of ovulatory mechanisms by postnatal administration of estrogen to the rat. Am J Physiol 1963; 205: 842-844. 
19 Bakker J, De Mees C, Douhard O, Balthazart J, Gabant P, Szpirer J, Szpirer C. Alpha-fetoprotein protects the developing female mouse brain from masculinization and defeminization by estrogens. Nat Neurosci 2006; 9: 220-226.

20 De Mees C, Laes JF, Bakker J, Smitz J, Hennuy B, Van Vooren P, Gabant P, Szpirer J, Szpirer C. Alpha-fetoprotein controls female fertility and prenatal development of the gonadotropin-releasing hormone pathway through an antiestrogenic action. Mol Cell Biol 2006; 26: 2012-2018.

21 Messager S, Chatzidaki EE, Ma D, Hendrick AG, Zahn D, Dixon J, Thresher RR, Malinge I, Lomet D, Carlton MB, Colledge WH, Caraty A, Aparicio SA. Kisspeptin directly stimulates gonadotropin-releasing hormone release via G protein-coupled receptor 54. Proc Natl Acad Sci USA 2005; 102: 1761-1766.

22 Gottsch ML, Cunningham MJ, Smith JT, Popa SM, Acohido BV, Crowley WF, Seminara S, Clifton DK, Steiner RA. A role for kisspeptins in the regulation of gonadotropin secretion in the mouse. Endocrinology 2004; 145: 4073-4077.

23 Patterson M, Murphy KG, Thompson EL, Patel S, Ghatei MA, Bloom SR. Administration of kisspeptin-54 into discrete regions of the hypothalamus potently increases plasma luteinising hormone and testosterone in male adult rats. J Neuroendocrinol 2006; 18: 349-354.

24 Redmond JS, Macedo GG, Velez IC, Caraty A, Williams GL, Amstalden M. Kisspeptin activates the hypothalamic-adenohypophyseal-gonadal axis in prepubertal ewe lambs. Reproduction 2011; 141: 541-548.

25 Plant TM, Ramaswamy S, Dipietro MJ. Repetitive activation of hypothalamic $G$ protein-coupled receptor 54 with intravenous pulses of kisspeptin in the juvenile monkey (Macaca mulatta) elicits a sustained train of gonadotropin-releasing hormone discharges. Endocrinology 2006; 147: 1007-1013.

26 Dhillo WS, Chaudhri OB, Thompson EL, Murphy KG, Patterson M, Ramachandran R, Nijher GK, Amber V, Kokkinos A, Donaldson M, Ghatei MA, Bloom SR. Kisspeptin-54 stimulates gonadotropin release most potently during the preovulatory phase of the menstrual cycle in women. J Clin Endocrinol Metab 2007; 92: 3958-3966.

27 Pineda R, Garcia-Galiano D, Roseweir A, Romero M, Sanchez-Garrido MA, Ruiz-Pino F, Morgan K, Pinilla L, Millar RP, Tena-Sempere M. Critical roles of kisspeptins in female puberty and preovulatory gonadotropin surges as revealed by a novel antagonist. Endocrinology 2010; 151: 722-730.

28 Millar RP, Roseweir AK, Tello JA, Anderson RA, George JT, Morgan K, Pawson AJ. Kisspeptin antagonists: unraveling the role of kisspeptin in reproductive physiology. Brain Res 2010; 1364: 81-89.

29 Herbison AE. Estrogen positive feedback to gonadotropin-releasing hormone $(\mathrm{GnRH})$ neurons in the rodent: the case for the rostral periventricular area of the third ventricle (RP3V). Brain Res Rev 2008; 57 : 277-287.

30 Clarkson J, Herbison AE. Postnatal development of kisspeptin neurons in mouse hypothalamus; sexual dimorphism and projections to gonadotropin-releasing hormone neurons. Endocrinology 2006; 147: 58175825.

31 Kauffman AS. Gonadal and non-gonadal regulation of sex differences in hypothalamic Kiss1 neurons. J Neuroendocrinol 2010; 22: 682-691.

32 Adachi S, Yamada S, Takatsu Y, Matsui H, Kinoshita M, Takase K, Sugiura $H$, Ohtaki $T$, Matsumoto $H$, Uenoyama $Y$, Tsukamura $H$, Inoue $K$, Maeda K. Involvement of anteroventral periventricular metastin/kisspeptin neurons in estrogen positive feedback action on luteinizing hormone release in female rats. J Reprod Dev 2007; 53: 367-378.

33 Franceschini I, Lomet D, Cateau M, Delsol G, Tillet Y, Caraty A. Kisspeptin immunoreactive cells of the ovine preoptic area and arcuate nucleus co-express estrogen receptor alpha. Neurosci Lett 2006; 401: 225-230.
34 Clarkson J, d'Anglemont de Tassigny X, Moreno AS, Colledge WH, Herbison AE. Kisspeptin-GPR54 signaling is essential for preovulatory gonadotropin-releasing hormone neuron activation and the luteinizing hormone surge. J Neurosci 2008; 28: 8691-8697.

35 Smith JT, Cunningham MJ, Rissman EF, Clifton DK, Steiner RA. Regulation of Kiss1 gene expression in the brain of the female mouse. Endocrinology 2005; 146: 3686-3692.

36 Couse JF, Hewitt SC, Bunch DO, Sar M, Walker VR, Davis BJ, Korach KS. Postnatal sex reversal of the ovaries in mice lacking estrogen receptors alpha and beta. Science 1999; 286: 2328-2331.

37 Couse JF, Yates MM, Walker VR, Korach KS. Characterization of the hypothalamic-pituitary-gonadal axis in estrogen receptor (ER) Null mice reveals hypergonadism and endocrine sex reversal in females lacking ERalpha but not ERbeta. Mol Endocrinol 2003; 17: 1039-1053.

38 Herbison AE, Pape JR. New evidence for estrogen receptors in gonadotropin-releasing hormone neurons. Front Neuroendocrinol 2001; 22: 292-308.

39 Dungan HM, Gottsch ML, Zeng H, Gragerov A, Bergmann JE, Vassilatis DK, Clifton DK, Steiner RA. The role of kisspeptin-GPR54 signaling in the tonic regulation and surge release of gonadotropin-releasing hormone/luteinizing hormone. J Neurosci 2007; 27: 12088-12095.

40 d'Anglemont de Tassigny X, Ackroyd KJ, Chatzidaki EE, Colledge WH. Kisspeptin signaling is required for peripheral but not central stimulation of gonadotropin-releasing hormone neurons by NMDA. J Neurosci 2010; 30: 8581-8590.

41 Mayer C, Boehm U. Female reproductive maturation in the absence of kisspeptin/GPR54 signaling. Nat Neurosci 2011; 14: 704-710.

42 Bakker J, Honda S, Harada N, Balthazart J. The aromatase knock-out mouse provides new evidence that estradiol is required during development in the female for the expression of sociosexual behaviors in adulthood. J Neurosci 2002; 22: 9104-9112.

43 Bakker J, Pierman S, Gonzalez-Martinez D. Effects of aromatase mutation (ArKO) on the sexual differentiation of kisspeptin neuronal numbers and their activation by same versus opposite sex urinary pheromones. Horm Behav 2010; 57: 390-395.

44 Toda K, Takeda K, Okada T, Akira S, Saibara T, Kaname T, Yamamura K, Onishi S, Shizuta Y. Targeted disruption of the aromatase P450 gene (Cyp19) in mice and their ovarian and uterine responses to 17betaoestradiol. J Endocrinol 2001; 170: 99-111.

45 Clarkson J, Boon WC, Simpson ER, Herbison AE. Postnatal development of an estradiol-kisspeptin positive feedback mechanism implicated in puberty onset. Endocrinology 2009; 150: 3214-3220.

46 Honda S, Harada N, Ito S, Takagi Y, Maeda S. Disruption of sexual behavior in male aromatase-deficient mice lacking exons 1 and 2 of the cyp19 gene. Biochem Biophys Res Commun 1998; 252: 445-449.

47 Fisher $C R$, Graves $K H$, Parlow AF, Simpson ER. Characterization of mice deficient in aromatase (ArKO) because of targeted disruption of the cyp19 gene. Proc Natl Acad Sci USA 1998; 95: 6965-6970.

48 Bakker J, Honda S, Harada N, Balthazart J. Sexual partner preference requires a functional aromatase (cyp19) gene in male mice. Horm Behav 2002; 42: 158-171.

49 Gonzalez-Martinez D, De Mees C, Douhard O, Szpirer C, Bakker J. Absence of gonadotropin-releasing hormone 1 and Kiss1 activation in alpha-fetoprotein knockout mice: prenatal estrogens defeminize the potential to show preovulatory luteinizing hormone surges. Endocrinology 2008; 149: 2333-2340.

50 Franklin KBJ, Paxinos G. The Mouse Brain in Stereotaxic Coordinates. San Diego, CA: Academic Press, 1997.

51 Lamberts R, Goldsmith PC. Fixation, fine structure, and immunostaining for neuropeptides: perfusion versus immersion of the neuroendocrine hypothalamus. J Histochem Cytochem 1986; 34: 389-398. 
52 Brock 0, Baum MJ, Bakker J. The development of female sexual behavior requires prepubertal estradiol. J Neurosci 2011; 31: 5574-5578.

53 Britt KL, Drummond AE, Cox VA, Dyson M, Wreford NG, Jones ME, Simpson ER, Findlay JK. An age-related ovarian phenotype in mice with targeted disruption of the Cyp 19 (aromatase) gene. Endocrinology 2000; 141: 2614-2623.

54 Liew SH, Drummond $A E$, Jones ME, Findlay JK. The lack of estrogen and excess luteinizing hormone are responsible for the female ArKO mouse phenotype. Mol Cell Endocrinol 2010; 327: 56-64.

55 Smith JT, Dungan HM, Stoll EA, Gottsch ML, Braun RE, Eacker SM, Clifton DK, Steiner RA. Differential regulation of KiSS-1 mRNA expression by sex steroids in the brain of the male mouse. Endocrinology 2005; 146: 2976-2984.

56 Toda K, Hayashi Y, Ono M, Saibara T. Impact of ovarian sex steroids on ovulation and ovulatory gene induction in aromatase-null mice. Endocrinology 2012; 153: 386-394.

57 Kauffman AS, Gottsch ML, Roa J, Byquist AC, Crown A, Clifton DK, Hoffman GE, Steiner RA, Tena-Sempere M. Sexual differentiation of Kiss1 gene expression in the brain of the rat. Endocrinology 2007; 148: 1774-1783.

58 Navarro VM, Sanchez-Garrido MA, Castellano JM, Roa J, Garcia-Galiano D, Pineda R, Aguilar E, Pinilla L, Tena-Sempere M. Persistent impairment of hypothalamic KiSS-1 system after exposures to estrogenic compounds at critical periods of brain sex differentiation. Endocrinology 2009; 150: 2359-2367.
59 Waters EM, Simerly RB. Estrogen induces caspase-dependent cell death during hypothalamic development. J Neurosci 2009; 29: 97149718.

60 Semaan SJ, Murray EK, Poling MC, Dhamija S, Forger NG, Kauffman AS. BAX-dependent and BAX-independent regulation of Kiss1 neuron development in mice. Endocrinology 2010; 151: 5807-5817.

61 Erskine MS, Tobet SA, Baum MJ. Effect of birth on plasma testosterone, brain aromatase activity, and hypothalamic estradiol in male and female ferrets. Endocrinology 1988; 122: 524-530.

62 Baum MJ, Brand T, Ooms M, Vreeburg JT, Slob AK. Immediate postnatal rise in whole body androgen content in male rats: correlation with increased testicular content and reduced body clearance of testosterone. Biol Reprod 1988; 38: 980-986.

63 Semaan SJ, Kauffman AS. Sexual differentiation and development of forebrain reproductive circuits. Curr Opin Neurobiol 2010; 20: 424431.

64 Smith JT. Kisspeptin signalling in the brain: steroid regulation in the rodent and ewe. Brain Res Rev 2008; 57: 288-298.

65 Clarkson J, Herbison AE. Dual phenotype kisspeptin-dopamine neurones of the rostral periventricular area of the third ventricle project to gonadotrophin-releasing hormone neurones. J Neuroendocrinol 2011; 23: 293-301.

66 Smith JT, Popa SM, Clifton DK, Hoffman GE, Steiner RA. Kiss1 neurons in the forebrain as central processors for generating the preovulatory luteinizing hormone surge. J Neurosci 2006; 26: 6687-6694. 